\title{
FEATURES OF THE ORGANIZATION AND PROVISION OF EMERGENCY MEDICAL CARE IN POLTAVA REGION
}

D0l:10.36740/WLek202102132

\author{
Iryna A. Holovanova, Oksana I. Krasnova, Svetlana M. Tanianskaia, Irina A. Kolenko, Mariya 0. Rumyantseva, \\ Natalia A. Lyakhova, Oleh H. Krasnov \\ UKRAINIAN MEDICAL STOMATOLOGICAL ACADEMY, POLTAVA, UKRAINE
}

\begin{abstract}
The aim: Is to study and analyze the dynamics of the indicators of the emergency medical service of the Ukrainian and the Poltava region in the context of the reforms of the healthcare system in Ukraine.

Materials and methods: In this work, the indicators of development of the emergency medical service of the Ukrainian and the Poltava region were studied and analyzed. Conclusions: The provision of emergency medical care in the Poltava region is provided by the Poltava Regional Center for Emergency Medicine and Disaster Medicine. The structure of the center includes 4 emergency medical stations, which are located in cities such as Poltava, Kremenchuk, Lubny, Mirgorod. A modern telemedicine center was built in 2018 for emergency counseling on-line in new directions was carried out: ultrasound and endoscopic diagnostics, radiology, counseling during surgical interventions, laboratory diagnostics, etc. Emergency medical care reform Poltava Regional should be aimed at increasing the efficiency of the use of resources; provision of the EMC system by the relevant vehicles; qualitative training of doctors in emergency medicine; informatization of the EMC system.
\end{abstract}

KEY WORDS: emergency medical care, health care system, reformation of health care system

Wiad Lek. 2021;74(2):351-354

\section{INTRODUCTION}

Social and economic problems in Ukraine had a negative impact on the health care system and caused a difficult demographic situation in the country. Year after year, a lot of people die due to the lack of timely qualified medical care, this is especially true for patients with acute myocardial infarction $[1,2]$.

The main reasons of this situation are: improper organization of the network of emergency medical care centers and patient routes, technical condition of ambulances and low financial support. This showed the need for quick measures to reform the medical industry and, especially, the emergency medical service. The government pays particular attention to the improvement and development of this part of the medical sector $[3,4]$. It is known that the life expectancy of patients depends on the work of ambulance, the active working period of people extends and their quality of life improves [5].

\section{THE AIM}

To analyze the state of the emergency medical care condition of Poltava region during the reform of the emergency medical care in Ukraine

\section{MATERIALS AND METHODS}

The analysis and systematization of indicators of the condition of emergency medical care in the Poltava region.
Medical and statistical methods were used to collect, process and analyze data.

\section{REVIEW}

Analyzing the state of resource provision of the emergency medical care system in Ukraine, it should be noted that today, emergency medical care is provided by $2954 \mathrm{ambu}$ lance teams, of which 1867 are paramedic teams. It should be noted that emergency medical aid teams are staffed with doctors by $62 \%$, and junior specialists with medical education by $86 \%$ [6].

The structure of ambulance brigades and the time of arrival of the brigades to the call are shown in Table I.

During the study period, the number of emergency medical aid teams practically did not changed, but there was an increase in paramedic teams with a reduction in general medical and specialized medical teams. The indicator of the timely arrival of the ambulance team on call in the city and countryside has decreased, possibly due to the need to update the park of specialized ambulances.

The provision of emergency medical care in the Poltava region is provided by the Poltava Regional Center of Emergency Medicine and Disaster Medicine.

The center provided emergency medical assistance to the population of the region of 1,405,99 thousand people, including 867,200 urban population and 538,800 rural people. 
Table I.. The dynamics of the number of emergency medical teams and staffing of emergency medical care transport in 2017-2019.

\begin{tabular}{ccccccc}
\hline & \multicolumn{4}{c}{$\begin{array}{c}\text { Emergency medical teams } \\
\text { (absolute number) }\end{array}$} & \multicolumn{2}{c}{$\begin{array}{c}\text { The arrival time of the emergency } \\
\text { medical brigade, \% }\end{array}$} \\
\cline { 2 - 7 } & Total & $\begin{array}{c}\text { Specialized } \\
\text { ones }\end{array}$ & $\begin{array}{c}\text { General medical care } \\
\text { professionals }\end{array}$ & $\begin{array}{c}\text { Medical } \\
\text { paramedics }\end{array}$ & Done & Up to 20 min \\
\hline 2017 & 2922 & 137 & 994 & 1790 & 93,3 & 87,8 \\
\hline 2018 & 2948 & 138 & 989 & 1824 & 91,6 & 88,8 \\
\hline 2019 & 2955 & 109 & 1000 & 1845 & 92.3 & 85,4 \\
\hline
\end{tabular}

The structure of the center includes 4 emergency medical stations, which are located in such cities as Poltava, Kremenchuk, Lubny, Mirgorod, which include 24 substations and 22 points of permanent and temporary deployment of teams. The center for emergency medical care and disaster medicine is staffed by $75 \%[7,8,9]$.

The staffing rate of the Emergency Medical Center with individuals is 69\% (in $2017-70 \%$ ), and staff positions are occupied by $75 \%$. It should be noted that the percentage of medical workers with a qualification category is $77 \%$. At the same time, in 2018,67 doctors and 214 junior specialists with medical education took advanced training courses. The educational department trained 162 medical specialists (including Kremenchug, Lubensky and Mirgorodsky districts).

Ambulance crews are equipped with new medical equipment. It was received from the World Bank's funds under the project "Improving Health Care in the Service of People" (subproject "Implementing an Innovative Model for the provision of services for patients with hypertension in Poltava Region"). Were received two modern ambulances and 100 electrocardiographs with remote data transfer, which made it possible to increase the detection rate of acute cardiac pathology $[2,3]$.

According to the results of the work of the regional emergency medical service in 2018, the teams of the Poltava Regional Center for Emergency Medicine and Disaster Medicine served more than 314,000 emergency requests a medical doctor, what is $10.4 \%$ less than in 2017 (more than 350,000 calls).

That was achieved by reducing the number of unreasonable calls by providing the public with information about the work of the emergency medical service. Generally, the share of calls to the countryside increased $-26,7 \%$, instead of $26,3 \%$ during the past year, which had a positive impact on the provision of medical care to the rural population.

During the visit to the site of the brigades of the Poltava Regional Center for Emergency Medicine and Disaster Medicine, more than 300,000 people were provided with medical assistance in 2018. At the same time, about 26,000 patients were provided with outpatient care at the Emergency Medicine Center in 2018.

In 2018, in the Poltava region, the number of people assisted by the emergency medical service increased by $62,2 \%$ (186.974) people, compared with $60.5 \%$ in 2017 . In 2018 , the share of people delivered by ambulance teams for hospitalization increased to $26.8 \%$ ( 84,339 people) of the total number of visits compared to $25.3 \%$ (88,900 people) in
2017, which improved the quality of medical help. In 2018 , $5.1 \%(4,319)$ people were delivered to medical directions of medical institutions, which is more than in $2017-3.9 \%$ $(3,499)$ people.

The number of visits by ambulance crews that ascertained death was 3.063 in 2018, which is $1 \%$ of the total number of visits and, at the 2017 level, $1 \%$ of the total number of visits (3,291 visits).

If we consider the indicators of the timely arrival of teams to the patient, then there have been no significant changes, so in the city, $97 \%$ of emergency medical care teams arrived at the patient within 10 minutes from the moment of connection in 2018 (2017 - 96.8\%). In rural areas, 96.8\% of emergency medical teams arrived to the patient within up to 20 minutes from the moment of connection in 2018 (2017 -96.4\%). As modern studies show, the timely arrival of the emergency medical team to the patient significantly reduces the risk of complications of the disease and the percentage of mortality, including in acute cardiovascular pathology [10].

In $2018,1,085$ advisory visits to medical institutions of the region were completed and 376 patients were delivered to institutions of the third and fourth levels of medical care.

Electronic registers of applications to medical institutions of the Poltava region for medical assistance from displaced persons from certain areas of the Luhansk and Donetsk regions are maintained. In 2018, more than 15 thousand such requests were registered. It also maintains registers of emergencies that have occurred in the region, and the number of volunteers trained in medical care skills.

In accordance with the Law of Ukraine "On Emergency Medical Aid" and the national project "Timely Help", the operational dispatching service of the emergency medical center functions. In 2018, the phased connection of 10 substations of the largest district of the center to the call routing service to the short number "103" using the modern SIP-trunk protocol was completed. In these areas, the introduction of a remote workstation for the head of the visiting team of emergency medical care with work on tablets with a mobile application was ensured.

A modern telemedicine center was built in 2018 for emergency counseling on-line in new directions was carried out: ultrasound and endoscopic diagnostics, radiology, counseling during surgical interventions, laboratory diagnostics, etc. Taken the measures to implement the work of a portable ultrasound machine on emergency health care teams for emergency diagnosis at the prehospital stage. 


\section{DISCUSSION}

Thus, we see that the staffing of emergency medical aid teams with doctors is insufficient [6]. There is a personnel problem in the staffing of the Poltava Regional Center for Emergency Medicine and Disaster Medicine, and insufficient qualification training of medical personnel.

Funding and provision of the center with equipment and vehicles is inadequate and is partially compensated by the assistance of the World Bank in the framework of the project "Improving Health in the Service of People".

Despite this, there have been positive changes in the system of emergency medical care in the Poltava region, especially the rural population. Thus, the number of unmotivated calls to emergency medical teams decreased, the number of episodes of emergency medical care, including those with acute cardiovascular pathology, increased, the number of specialized care increased, and the time of arrival of the emergency medical team decreased.

Also, the connection of substations to the call routing service using the modern SIP-trunk protocol and the introduction of a remote workplace for the head of the ambulance team were completed. The telemedicine center allows them to provide emergency medical care on-line.

As we can see, the Government of Ukraine is actively continuing to reform the medical industry in the country. An important area of medical care is improving the quality of emergency medical care in Ukraine $[4,5]$.

The main problems of the ambulance service that require improvement are the legal framework, informatization and use of the electronic document management system, the interaction of all structural units of the emergency medical care center, the correct work of personnel and the availability of modern vehicles $[4,5]$. The development of informatization of the health care system and especially the ambulance sector is one of the important areas of reform at the present stage.

\section{CONCLUSIONS}

Thus, reforming the emergency medical care of the city of Poltava will significantly improve the quality and availability of emergency medical care urban and rural population. In the future, emergency care reform should be aimed at: improving the efficiency of use of emergency health care resources; increasing the availability and quality of emergency health care; the population and health workers should be positive about emergency health care reform; providing the emergency health care system with modern vehicles; ensuring the quality training of emergency medical doctors to the extent necessary for serving the population; improvement of the system of professional development of junior medical specialists of the emergency health care centers; development of new methods of employee motivation.

\section{REFERENCES}

1. Shorichna dopovid' pro stan zdorov'ya naselennya, sanitarnoepidemichnu situaciyu ta rezul'tati diyal'nosti sistemi ohoroni zdorov'ya Ukraini 2016. [Annual report on the state of health of the population, the sanitary-epidemic situation and the results of activity of the health care system of Ukraine 2016]. K. 2017: 438. (in Ukrainian).
2. Zhdan V.M., Holovanova I.A., Kasynets S.S. et al. The analysis of implementation of cardiovascular disease primary prevention at the primary healthcare level. Public Health Forum. 2016;3(3):138-141.

3. Holovanova I.A., Kasynets S.S., Khorosh M.V. et al. Suchasni problemy' profilakty 'ky' xvorob sy 'stemy' krovobigu na pervy 'nnomu rivni. [Modern problems of prevention of diseases of the circulatory system at the primary level]. Sotsial'na farmatsiya v okhoroni zdorov"ya. 2016; 2 (4):11-16. (in Ukrainian).

4. Zhdan V.M., Holovanova I.A., Gavlovsky`j 0.D. et al. Organizaciya nadannya medy 'chnoyi dopomogy 'naselennyu $v$ period reformuvannya sfery` oxorony' zdorov'ya Ukrayiny'. [Organization of provision of medical care to the population during the period of reforming the sphere of health care in Ukraine]. Poltava. 2018: 78-68. (in Ukrainian).

5. Lyakhova N.O., Bielikova I.V., Holovanova I.A. Derzhavna polityka shchodo realizatsii prava hromadian na medychnu dopomohu v Ukraini [State policy on realization of citizens'right to medical care in Ukraine]. Materialy Chetvertoi Vse-ukrainskoi naukovo-praktychnoi konferentsii «Teoretyko-pravovizasady formuvannia suchasnoho medychnoho prava v Ukraini». Poltava. 2015: 24-26 (in Ukrainian).

6. Holovanova I.A., Kasynets S.S., Krasnova 0.I. et al. The modern situation with emergency medical care in Ukraine in the conditions of reform: problems and perspectives. Emergency medical servsce, 2018; 5 (2): 63-67.

7. Demografiya y` social 'na staty'sty 'ka. Oxorona zdorovya. Derzhavna sluzhba staty 'sty 'ky' Ukrayiny'. [Demography and social statistics. Health care. State Statistics Service of Ukraine], 2018. doi: http//ukrstat. org. (in Ukrainian).

8. Holovanova I.A., Bielikova I.V., Lyakhova N. 0. Osnovy medychnoi statystyky. Navchalnyi posibnyk [Fundamentals of medical statistics. Textbook]. Poltava. 2017: 111. (in Ukrainian).

9. Krasnova 0.I. Stan ta problemy' rozvy tku finansuvannya oxorony zdorov'ya v sil's 'kij miscevost [State and problems of rural health financing development]. Internauka. 2018; 1 (9): 39-46. (in Ukrainian).

10. Holovanova I.A., Oksak H.A., Khorosh M.V. et al. Faktory ryzyku, poviazani z vynyknenniam rannikh uskladnen hostroho infarktu miokarda pislia kardiointerventsiinoho likuvannia [Risk factors associated with early complications of acute myocardial infarction after cardiac intervention]. Modern medical technologies. 2020; 2: 84-90. (in Ukrainian).

The work is a fragment of SRR "Medical and social rationale for optimizing approaches to managing and organizing various types of medical care for adults and children in the period of reforming the health care industry" (№ St. Registered 0119U102926 term of performance 2018-2022 year).

\section{ORCID and contributionship:}

Iryna A. Holovanova: 0000-0002-8114-8319 A,F

Oksana I. Krasnova: 0000-0001-9819-1818 B,D

Svetlana M. Tanianskaia: 0000-0003-3764-2181 ${ }^{B}$

Irina A. Kolenko: 0000-0003-2124-4509 ${ }^{B}$

Mariya O.Rumyantseva: 0000-0001-7247-9792 ${ }^{B}$

Natalia A. Lyakhova: 0000-0003-0503-9935 C, E

Oleh H. Krasnov: 0000-0002-8704-1686 ${ }^{B, D}$

\section{Conflict of interest:}

The Authors declare no conflict of interest. 


\section{CORRESPONDING AUTHOR}

\section{Oksana I. Krasnova}

Ukrainian Medical Stomatological Academy

23 Shevchenko st., 36000 Poltava, Ukraine

tel: +380984673750

e-mail:krasnovaoksana197@gmail.com

Received: 20.03 .2020

Accepted: 17.11 .2020

A - Work concept and design, B - Data collection and analysis, C - Responsibility for statistical analysis,

D-Writing the article, $\mathbf{E}-$ Critical review, $\mathbf{F}-$ Final approval of the article 